\title{
EDITORIAL
}

\section{Monitoreo hídrico en la Viticultura Chilena y su aplicación en otras zonas}

\author{
Water monitoring in Chilean Viticulture and \\ its application in other areas
}

\section{Richard Marcelo Bustos Peña Universidad de Tarapacá}

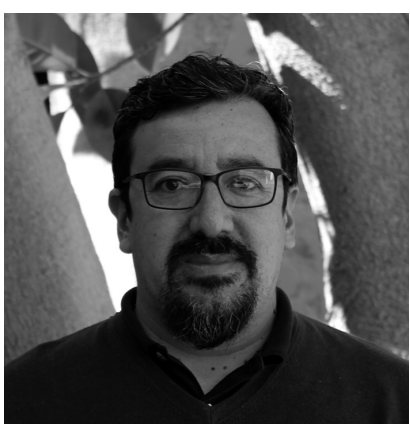

Richard Marcelo Bustos Peña

University of Tarapacá
La vitivinicultura es un sector de gran dinamismo en Chile. Esta industria se ha especializado de manera creciente en vinos de alta calidad aprovechando las condiciones particulares de clima y suelo que presentan los valles vitivinícolas. Los vinos chilenos han liderado el desarrollo exportador del país, contribuyendo a reforzar la imagen de Chile como proveedor de productos agrícolas de calidad y coadyuvando así a abrir camino a otros productos de la agricultura. La viticultura nacional abarca desde la región de Tarapacá por el norte hasta la región de Los Lagos por el sur, con una mayor concentración en la región del Maule. Una de las razones de este desarrollo son los avances tecnológicos utilizados en el proceso de producción, especialmente en el manejo del riego que incide en la calidad de la fruta, el rendimiento y el producto final (vino).

El manejo hídrico en vides es muy importante ya que se ha demostrado que las vides bajo cierto umbral de estrés hídrico logran controlar el vigor vegetativo y permiten la expresión de algunos factores de calidad en las bayas. Por otro lado, se busca optimizar el recurso hídrico debido a la disminución de las precipitaciones anuales por efecto del cambio climático a nivel global, estimulando a los productores a mejorar las estrategias de riego para aumentar la eficiencia en el uso del agua.

El efecto del cambio climático podría afectar la disponibilidad de los recursos hídricos, lo que
Winegrowing is a very dynamic sector in Chile. This industry has increasingly specialized in high-quality wines, taking advantage of the wine-producing valleys' particular climate and soil conditions. Chilean wines have led the country's export development, contributing to reinforcing Chile's image as a supplier of quality agricultural products and thus helping to open the way to other agricultural products. The national viticulture reaches from the Tarapaca region in the north to Los Lagos region in the south, with a higher concentration in the Maule region. One of the reasons for this development is the technological advances used in the production process, especially in irrigation management, which affects the quality of the fruit, the yield, and the final product (wine).

Water management in vines is essential since it has been shown that vines under a certain threshold of water stress manage to control vegetative vigor and allow the expression of some quality factors in the berries. Additionally, it seeks to optimize water resources because of the decrease in annual rainfall due to climate change at a global level, encouraging producers to improve irrigation strategies to increase water use efficiency.

The influence of climate change could affect water resources availability, which represents a new challenge for the sustainable development of productive systems. This effect can be seen in the 
representa un nuevo desafío para el desarrollo sustentable de los sistemas productivos. Este efecto se observa en el incremento significativo en la temperatura promedio y la reducción de las precipitaciones anuales. Como consecuencia de estos cambios, las regiones podrían experimentar sequías cada vez más severas, donde el manejo del riego permite asegurar la demanda de agua del cultivo. Por esta razón, la determinación precisa de las necesidades hídricas en vides es muy importante para la planificación y gestión de los recursos hídricos.

En la actualidad los métodos micrometeorológicos, como Eddy Covariance, relación de Bowen y Surface Renewal, usados para estimar la evapotranspiración del cultivo, son considerados muy eficientes y precisos. Estos métodos se basan en la ecuación del balance de energía superficial, que considera todas las pérdidas del sistema por evaporación de agua. Los métodos para estimación de evapotranspiración como la relación de Bowen o el Sistema Eddy Covariance son difíciles de operar, tienen un alto costo y requieren un cuidadoso mantenimiento, lo que dificulta su uso y aplicación de manera extensiva en la agricultura tradicional. Por ello quedan restringidos a la academia y la investigación científica.

Sin embargo, a finales de los 90, varios investigadores de UC Davis desarrollaron una nueva metodología para realizar monitoreo hídrico en cultivos denominada Surface Renewall (renovación superficial). Este es un método sencillo, de bajo costo y que no requiere personal altamente calificado para su operación. Diversas investigaciones apoyan el trabajo y los resultados obtenidos. En industrias de vitivinicultura de gran importancia se han desarrollado ensayos con esta tecnología con buenos resultados. Además, se han reportado trabajos en otros cultivos y en otros sistemas productivos como invernaderos. Estos resultados sugieren buenas perspectivas para el desarrollo de esta tecnología en las zonas del norte de nuestro país, que dadas sus características de cultivo en condiciones áridas o semiáridas, requieren más precisión en la estimación de las necesidades hídricas y el monitoreo hídrico de los cultivos. significant increase in average temperature and the reduction in annual rainfall. As a result of these changes, regions could experience increasingly severe droughts, where irrigation management makes it possible to ensure the crop's water demand. Therefore, the precise determination of the water needs in vines is crucial for the planning and management of water resources.

Micrometeorological methods, such as Eddy Covariance, Bowen ratio, and Surface Renewal, used to estimate crop evapotranspiration, are considered very efficient and accurate. These methods are based on the surface energy balance equation, which considers all system losses due to water evaporation. Methods for evapotranspiration estimation such as the Bowen ratio or the Eddy Covariance System are complex to operate, have a high cost, and require thorough maintenance, making it intricate to use and apply extensively in traditional agriculture. For this reason, they are restricted to academia and scientific research.

However, in the late 1990s, several UC Davis researchers developed a new methodology for crop water monitoring called Surface Renewal. This method is a simple, low-cost system that does not require highly qualified personnel to operate. Several investigations support the work and the obtained results. Tests with this technology have been developed in prominent wine industries with considerable results. Furthermore, works in other crops and other productive systems such as greenhouses have been reported. These results suggest valuable perspectives for the development of this technology in the northern areas of our country, which, given their cultivation characteristics in arid or semi-arid conditions, require more precision in estimating water needs and water monitoring of crops. 